\title{
Becoming a (male) foundation phase teacher: A need in South African schools?
}

\author{
Nontokozo Mashiya, University of Zululand.*
}

\begin{abstract}
This paper reports on a case study of male foundation phase pre-service students who were among the first cohort to specialise in the foundation phase since the inception of the programme at one South African university. The students reported on their experiences of teaching in a female-dominated field and their views about their preparedness to teach in the field. This qualitative study is interpretive in nature. Using purposive sampling, eighteen students were sampled from a population of twenty. Data was generated through focus group interviews and then analysed and categorised. The patterns across categories showed that the pre-service teachers had faced an unwelcoming environment in the schools at the outset, but that this changed over time. Some parents were negative about male teachers in the foundation phase. However, the pre-service teachers were able to work hard and show that they can work with foundation phase learners. The study concluded that male students who enter foundation phase teacher education programmes need a lot of encouragement to boost their self-confidence and to realise the important role they can play in working with young children in a country where many young learners grow up in fatherless homes.
\end{abstract}

Keywords: male teachers, foundation phase (FP), fatherless children, social bias, classroom management, attitudes

*Email: MashiyaJ@unizulu.ac.za

South African Journal of Childhood Education | 2014 4(3): 24-36 | ISSN: 2223-7674 |๔ UJ

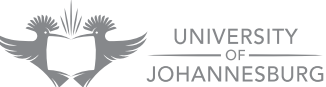




\section{Introduction: Men as teachers in the early grades}

The 'Strengthening Foundation Phase Teacher Education' project sought to strengthen foundation phase (FP) teacher education programmes in South Africa. The field of FP education is populated mostly by female teachers. In the past, this field was marginalised, but now is beginning to get attention and has become a niche area of educational development in the country. With the focus on this phase of education has come an interest from young men who wish to be teachers in the early grades.

Traditionally, few males have been involved in foundation phase education, but this is beginning to change. In Finland, the proportion of male elementary school teachers is 10\%; in Germany, it is 4\%; and in the United States (US), only $2 \%$ (atthechalkface.com/2012/12/08/just-an-observation-on-male-teachers). Gender prejudice and stereotyping loom large when it comes to reasons for the small number of men in childhood education settings, including that teaching young children is "a woman's job" (Drury 2008:314) and a lack of public acceptance due to perceptions about the 'unnaturalness' of males performing basic care tasks (Clyde 1994) and the stigma of male involvement in child abuse. In addition, primary school teaching is perceived as an "unattractive" profession for men - "boring, hassle causing, stressful or requiring too much patience" (Drury 2008:314) - with poor pay and promotional opportunities (Clyde 1994). A statement by a male preschool teacher in the US is illustrative of this:

Changing my major from engineering to teaching was easy because I felt passionate about teaching. Friends, however, gave me confused looks when I told them that I was in childhood education" (National Association for the Education of Young Children 2010:6).

As a result, few men choose to teach in primary schools (Drury 2008), or do so with other agendas in mind: a study by Ching-Sheue and Kun-Chung (2010) found that male teachers in Taiwan enter the field in order to open a preschool business or because they perceive the course content as being easier.

Sobiraj, Korek, Weseler and Mohr (2011) report on a study assessing specific attitudes toward the male role, particularly with regard to masculinity. The authors questioned female employees in female-dominated occupations about their attitudes towards men in these roles, including male teachers in German pre-schools, and asked their male colleagues to self-evaluate their psychological health. Sobiraj et al (ibid) define masculinity ideology as a set of beliefs and expectations about what men are like and should do. Based on this normative perspective, men face cultural standards about being a man. The authors found that males in female-dominated professions are perceived as performing stereotypically 'female' tasks and displaying feminine attributes, which is viewed as a violation of traditional notions of masculinity.

Research on attitudes towards male FP student teachers in South Africa indicates similar sentiments being harboured about male teachers teaching in the FP. According to Petersen and Petker (2011), teaching in the early grades is often accompanied by simplistic images of FP teachers as 'nannies' and 'caregivers,' both of which are generally associated with a woman's rather than a man's role in society. This is supported by a further study by Petersen (2014), which showed a cultural bias against 
male FP teachers: "[I]n the black culture, children are raised by their mothers, not their fathers" (ibid:6). Discomfort about having men teaching in the FP also stems from the fact that, according to one participant, men have "a lot of power and many children are scared of the 'father figure', so the public aren't comfortable with men in the FP" (ibid). Similar attitudes were displayed by some female preschool teachers in a Turkish study, who expressed concern that male preschool teachers are not good caregivers. One respondent observed that if she was a parent of girls, she would prefer not to have her daughter taught by males (Sak, Sahin \& Sahin 2012).

Sanders (2002) and Sargent (2001) point out that many men have little or no experience working and interacting with young children (birth to age 8), and their initial awkwardness may cause professors, supervisors, and families to judge them harshly. Sumsion (2005:112) writes about male teachers "facing the challenge of negotiating" what he calls their "otherness" in relation to their female counterparts. According to Sumsion, the scarcity of men in early childhood education may be ascribed to a perception that men who choose to work with young children are either principals in training, or homosexuals or paedophiles (ibid). This is supported by a study conducted by Mukuna \& Mutsotso (2011) in Kenya, which shows that the community is uneasy and suspicious about men who choose to work with young children in preference to entering higher status or better paid occupations; in the words of one respondent, "society refers to them as men who have not got their gender right" (ibid:1877). These studies are indicative of the troubling stereotypification of male teachers as sexual predators and paedophiles, and a persistent fear that they may sexually molest young children. This not only prevents male students from joining childhood education programmes, but also impacts on male teachers' working conditions; for example, Cooney and Bittner (2001) report that male teachers feel isolated and uncomfortable about discussing classroom issues with female colleagues for fear of their observations being misconstrued. More research on the issue of paedophilia and early years teaching is needed to rectify this situation and educate the community and even the teaching fraternity that not all men have such tendencies. Male staff wants to be able to work with young children without their motives being questioned and without being placed under constant scrutiny by administrators, other teachers, and parents for possibly being gay or paedophiles (Sargent 2001).

Notwithstanding the obstacles faced by men entering the field of early childhood education, there are signs that public and professional opinion is changing in this regard. In New Zealand, there is growing public concern over the disproportionately small number of male teachers teaching young children, and in the United States, the topic features prominently on social media platforms (http://www.takepart.com/ article/2013/07/19/we-need-more-male-elementary-school-teachers). The findings of a recent study in Turkey about parents' opinions about having their children taught by male preschool teachers reveal that parents whose children receive education from male teachers believe that men can perform this task as successfully as women (Akman, Taskin, Ozden, Okyay \& Cortu 2014), while Sak et al (2012) found that most female pre-service preschool teachers in Turkey also agree that there should be more 
male preschool teachers. The female teachers expressed the opinion that due to the increasing prominence given to childhood education, there are more opportunities in this field, which encourages more men to enter into preschool teaching, but felt that an active media campaign should be undertaken to make the general public more aware of the benefits of male pre-school teachers (ibid). Petersen (2014) notes that the findings of Akman et al (2014) regarding parents' views on the appointment of male teachers in Turkish preschools indicate that they are becoming less concerned about whether teachers are male or female, which means that there is likely to be an increasing number of male student teachers in foundation phase teacher education programmes in that country. Based on their own research, Sobiraj et al (2011) and Sak et al (2012) also conclude that the number of males in formerly female-dominated occupations is expected to rise in the future in countries such as Germany, the United States and Turkey.

Numerous studies have demonstrated the benefits of increased representation of male teachers in the foundation phase and a greater balance between the number of male and female teachers. Shonkoff, Richter, Van der Gaag and Bhutta (2012) point out that physical development theory of children in the preschool age group places an emphasis on gross and fine motor skills and the importance of physical activity in developing these skills. Physical activity therefore also forms an essential part of schooling in the early grades. Sak et al (2012) found that boys preferred to play with male teachers - perhaps, as Fagan (1996) and Lamb (2000) assert, because men bring more play, active movement, entertainment, and rough and tumble play to the way in which they interact not only with their own children, but also with those in a school programme. In addition, Sak et al (2012) found that female preschool teachers not only think that their male counterparts are innovative problem-solvers and better disciplinarians, but also that they support the development of children's social and emotional skills by serving as positive male role models. In the process, they also contribute towards removing bias against male teachers. Allen and Daly (2007) support these findings. According to them, children who have 'father figures' involved in their education are more likely to get better grades; have stronger verbal and problem-solving skills; perform better on achievement tests; demonstrate a higher tolerance for frustration; and are more likely to have positive peer relationships. These studies show that male teachers can work successfully with young children. Indeed, it is interesting to note that in Germany (Prussia) in 1901, only $15 \%$ of elementary school teachers were female, rising to $21 \%$ in 1921 (McClelland 2002).

In the South African context, Petersen and Petker (2011) suggest that the overarching goals of contributing to the building of a young nation and achieving social justice in education serve as motivation for more student teachers, male and female, to enter into PF education. Moreover, preconceptions of a 'motherly' type of professional as the ideal teacher for young children are being challenged by current trends in South Africa. It is my contention that this bodes well for the education of both male and female children, many of whom grow up in female-headed, singleparent households. 


\section{The inquiry}

This article reports on a qualitative study that was aimed at providing an in-depth view of male pre-service teachers' sense of their preparedness to teach in the foundation phase; their experiences of teaching practice in this field; and the possible educational benefits for children taught by male teachers. The participants were selected purposively to include eighteen male students from a group of twenty-two student teachers specialising in FP education. Only students who had teaching practice experience were included. For the sake of convenience and because it was considered easier to deal with a smaller, more manageable number of students at a time, the participants were divided into three focus groups of six students each.

The focus group interviews were transcribed and three steps were followed in the process of data analysis. The data was reduced to utilise only essential information and data analysis processes were displayed with labels for codes and categories. According to McMillan and Schumacher (1993), data reduction is a process that entails reading data sets to get a sense of the information, identifying topics, and categorising the data into themes. Conclusions were then drawn from these displays in the tradition first promoted by Miles and Huberman (1994).

\section{Ethical considerations}

The researcher was sensitive to the rights of participants. Ethical issues were explained to them and they were informed that the study was voluntary and that they could withdraw at any stage without fear of negative repercussions. Confidentiality was ensured and the names of participants were withheld. An ethical clearance certificate was obtained from the university where the study was registered.

\section{The findings: Male student teachers are vulnerable, but motivated}

The following themes were constructed from the analysed data: 1) the students' first encounter with the school during teaching practice was a novel experience in many ways for the school; 2) participants noted that there may be specific educational benefits for children being taught by male teachers; 3) they noted that the attitudes of stakeholders towards them was often apprehensive or negative; 4) they were acknowledged for positive contributions during teaching practice; 5) they believe that they are instrumental in turning the tide with regard to perceptions of male teachers in the early grades; and 6) practicing teachers and other student teachers regarded them as competent.

\section{The themes}

Male pre-service teachers' first encounter with the school during teaching practice: "Good morning, Miss!" 
In some areas of the province where the study was conducted, the idea of a male teacher teaching in the FP was unheard-of. Most students alluded to the fact that when they first arrived at schools for teaching practice as third-year students, the teachers who received and inducted them were shocked to hear that male student teachers would be teaching in the FP. The learners were likewise surprised to see male teachers in their classrooms. They did not know that a male teacher is called 'Sir' and would call them 'Miss'; grade R learners would call them 'Uncle'. The students and their school mentors had to explain to learners how they should be addressed.

The participants were taken aback by the degree of shock and surprise among teachers when they heard that male students would be doing their practice in FP. One student teacher commented as follows on his reception in the school:

The principal of the school was surprised that I wanted to be placed in the foundation phase and most of the time the principal was asking me: "Why?"

Other students felt discouraged by the comments of school teachers, for example:

I experienced discouragement from school teachers who were making fun of me. Some thought that I am not sure of what I am doing. They started explaining what foundation phase is as if I do not know.

Such comments were not limited to school teachers. The participants did their teaching practice with other student teachers specialising in other phases (intermediate, senior and FET), some of whom were from the same university as the FP student teachers and others from different universities. According to some of the participants, some of these students made fun of them, and even their peers from the same university continue to act as though specialising in FP teaching is not a clever choice. This is what one student said about his first encounter with other students doing teaching practice:

When we first entered the specialisation, we were the laughing stock of our counterparts. It was difficult; we wanted to deregister because we were not oriented to what foundation phase is. We thought that foundation phase allows one to teach from grade $\mathrm{R}$ through 7.

The above statements show that comments made out of ignorance discouraged some of the students. It also appears that some of them had not made an informed decision about their chosen specialisation due to a lack of proper orientation during admission.

\section{Educational benefits to FP learners taught by male teachers: interest and curiosity}

According to the respondents, their presence appeared to benefit the classes they taught in various ways. Learners were eager to participate in class activities and to spend more time with the male student teachers. Even those who were known by their teachers as not being diligent in the submission of completed activities would submit them on time when activities were presented by the student teacher. One student ascribed this to the novelty of having a male teacher: 
Learners are not used to male teachers. When they see us, there is a high level of curiosity. They think that as a male teacher you would say something in a different way.

Another student agreed with this, noting his experience with learners who struggled with phonics and spelling activities, but who mastered them under his tutelage. The student believed that this was due to a heightened interest in what he, as a male teacher, was teaching them.

Other students observed that their contribution to learners' academic achievement was triggered by the opportunity they gave learners to engage in physical activities:

The field is dominated by females, and most of them are not as young as we are and hence they lack the flexibility that we have. We take learners out to do outdoor activities and learners enjoy that. As a result their learning is enhanced, because we add a play component to their learning.

And:

Our strength in FP is in physical education. During teaching practice I observed that teachers are reluctant to take learners out, that is why they were excited when we were teaching them.

Other students raised the issue of discipline and classroom management. They stated that generally they do not shout, but are soft-spoken, an attribute that they associate with manhood and which they used to discipline learners:

I think we were good in disciplining children. I used to see that the class teacher would shout at the learners when they are making noise. I never shouted at them, by virtue of being a male, and learners stayed focused and intrigued. When they are speaking I would lower my voice and they would stop talking, because they want to hear what I am saying.

The following statement by one respondent serves to encapsulate the positive contribution to learners' academic performance by male student teachers:

My mentor gave me money (R150) on my last day. I had helped her encourage those learners who were seriously underachieving. During my stay, learners were interested in me. They would follow me and want to be with me during break. My presence and the way I taught and played with them motivated them. Their performance increased.

The above excerpts bear testimony to the possible educational benefits of having male teachers teach FP learners. Many of the students noted that the school teachers had commented on the progress they saw in their learners and were able to tell the students which aspects learners had improved on. The presence of the male student teachers in their classrooms had helped learners academically, while the bond they developed with the student teachers made them feel a sense of belonging. The most important contribution the students appear to have made was to give children the opportunity to play while still enforcing learning. Most students believed that their strength in FP teaching is to apply play in their teaching. 


\section{Attitudes of stakeholders towards male teachers who teach in FP}

Some teachers, especially the school principals, were quite happy to host male teachers in the FP, but others not so. The same applied to parents, with especially the parents of girl children expressing concern about male teaching FP learners:

After parents have heard that their children are taught by a male teacher, they would come to school and say, "You are the teacher of our children?"

The respondent who reported this reaction maintained that it was not just a simple question; rather, it showed parents' dissatisfaction at the prospect of having their FP children taught by a male teacher. Another student reported a similar reaction by a parent upon coming to school and finding a male pre-service teacher in a grade $\mathrm{R}$ classroom:

Our children are now taught by men.

The comment, by the parent of a girl child, was originally made in isizulu, in a tone reflecting much dissatisfaction with something that was new and not necessarily to be welcomed.

On the other hand, participants also noted that some parents were eager to come to school to see the male teachers teaching their children. Some parents displayed interest in what the students were doing and were impressed to see them teaching, and some even commended them for choosing to work with FP learners.

\section{Positive contributions made by student teachers while in schools during teaching practice}

The male student teachers contributed to the schools where they were placed in various ways. The students who participated in this study were notably involved in sporting activities and used their skills to assist with sports training, to the appreciation of principals. Some schools had sports equipment that was not in use, and students made use of this opportunity to make a positive contribution. The duration of teaching practice was ten weeks, which afforded the student teachers enough time to train learners and have them ready for competitions.

One student noted:

In the school I was teaching, there was cricket equipment which was not used. Fortunately I know how to play it. I started coaching learners in cricket. My learners entered for tournaments for the first time. The school was so proud of me. Even after teaching practice had ceased, the principal would come and pick me up so that I continue to train learners. This went on until I told the teacher that I am now preparing for examinations.

Other learners benefited from forming close bonds with the male student teachers. They felt at ease with the students and some even shared personal stories with them. One student teacher elaborated:

I gave learners love. I noticed that some were lacking a male figure in their lives. I could see in the way they would converse with me. During the story time, they would tell me stories and I would advise them and draw a moral lesson from 
what they are saying. During break, learners would follow me wherever I go and sometimes I would have to frown at them so that they see that I don't like that anymore and they would stop following me."

This response shows that learners formed a high level of attachment to the male student teachers. It also demonstrates that the male students are prepared to work with young children and give them the necessary care and attention they require, which, considering the fact that most learners in South Africa are fatherless or lack a father's touch, is in itself a very significant contribution.

\section{Turning the tide}

Most of the respondents noted that they were not much interested in FP teaching before they joined the programme and that they were not fully aware of what the field entails. Some of them only joined because they did not meet the entry requirements for other specialisations. First- and second-year students visit schools to observe only. During the third year, they get an opportunity to teach. It is clear that observation sessions do not adequately prepare students to understand that FP learners are not as very young as they appear, as they do not personally interact with the learners. However, the respondents noted that, at third-year level, after going out to schools to teach, they realised that FP learners are not as young as they perceived them to be during observation and that they are manageable.

Whereas they had not been enthusiastic about the field before - and although some expressed fear about being criticised by their fellow students and the community at large - most of the student teachers in the study professed to having accepted and dedicated themselves to early childhood education after their exposure during teacher practice:

When I entered FP I was not happy. With time I have grown to love the field and I am planning to pursue my studies on Early Childhood Education. I have fallen in love with the field so much.

And:

I like foundation phase teaching although I did not intend doing it. I have decided now that I am doing my Honours degree and I will focus on it, I have no intentions of changing.

\section{The opinion of others}

Participants reported having received positive feedback from school teachers and even student teachers specialising in the higher phases about how they handled the FP classes. One student noted:

When I was in class, teachers would come and watch me teach to see what I am doing with these young children. After watching they confessed that I know what I am doing."

Remarks such as this one suggest that the male students proved to be competent at teaching young learners and give some empirical evidence of their preparedness to teach in this contested space. 


\section{Discussion of findings}

The brief references above to study participants' comments suggest a whole new world to be examined and explored. One is left to wonder if the role of male teachers in childhood education has been undervalued and even misjudged in South Africa, where so many children lack positive male role models. The fact that some male students introduced sporting activities where there had previously not been any also offers food for thought. Sport and coaching do not exist in the FP sections of most schools, although the importance of physical activity for the development of gross and fine motor skills in children in this age group is well established.

Student teachers who end up in FP teaching in spite of criticism lobbied against them have a firm standpoint. Standpoint theory states that an individual's perspectives are shaped by his or her experiences in social locations and social groups (EdmondsCady 2009) and makes it clear that people choose what they want to do based on their standpoint (Wood 2008). The male students in this study have a strong focus on what they want to do with their lives. Some of them gained much personal satisfaction from their practice teaching and are planning to pursue further studies in childhood education. However, the study reveals that although some participants entered into the FP field because of prior experience of working with young children, especially as volunteer Sunday school teachers, others' first direct experience of working with young children was when they first did practice teaching. This poses problems when people have to exercise their rights regarding the choices they make about their future. This is evident in other studies; for example, the previously mentioned case of the student who received confused looks when he told friends of his intention to deregister from engineering and take a teaching qualification to teach elementary grades instead (National Association for the Education of Young Children 2010).

The participants in this study faced an unwelcoming environment when they first arrived at schools for practice teaching. Practicing teachers even explained the FP grade span to them, because they were under the impression that the students were confused about where they were going to do their practicum. The study supports the findings by Drury (2008) that primary school teaching is perceived as the domain of women: because the practicing teachers believe that FP is a field for women, they were taken by surprise when they saw male student teachers coming to teach in this phase.

The findings reveal that the male student teachers brought more play, active movement and fun to the way they interacted with learners, as is highlighted by the fact that they were able to assist the schools with sport and coaching using equipment that was not in use because of a shortage of expertise. They also demonstrated skill in holding learners' interest and disciplining them. Instead of shouting at learners, they spoke softly, compelling the learners to reduce noise in the classroom in order to hear what the teacher was saying.

The negative attitudes of all stakeholders, including parents, in-service teachers, other pre-service teachers and the community at large, towards male teachers in the 
FP are a cause for concern. Sumsion (2005:116) ascribes the "scarcity of men in early childhood education" to the perception that "men who choose to work with young children are homosexuals and paedophiles". This stigma tarnishes the image of all male students and teachers in the field of early childhood education and discounts the significant positive contributions of male teachers already teaching young children. The findings of the present study show that some learners showed significant academic improvement solely because they were taught by male teachers; some students were even given tokens of appreciation for helping learners who were at risk of failing the grade.

The male pre-service teachers in this study prided themselves on going beyond expectations by helping in whichever ways were needed in the schools. They stated that they had to take full charge of classes when their mentor teachers were absent, which included performing tasks such as dishing up food for learners during breaks and sweeping floors after they had eaten (most of the schools in the study had soup kitchens). This is in line with the finding of Sobiraj et al (2011) that males in femaledominated professions have to perform stereotypically 'female' tasks in order to gain acceptance.

\section{Conclusion and recommendations}

Very few male teachers currently teach in the foundation phase in South Africa, largely due to persistent cultural and societal bias against men working with young children. However, the findings of this study demonstrate that there are great educational and social benefits to be gained by incorporating male teachers into the foundation phase. Given these benefits, proper recruitment strategies should be applied to attract more male applicants to foundation phase teacher education programmes and more funding should be made available to assist male students who display a keen interest in this field. Proper attention should also be paid to proper orientation strategies for prospective students to assist them to make informed decisions regarding the choice of specialisation, as it appears that some students enter into foundation phase teacher education programmes without a thorough grasp of what it entails. In addition, male students in foundation phase teacher education programmes should be encouraged and educated about strategies to cope with criticism in order equip them to be resilient when they are faced with criticism of their choice. And finally, colloquia are needed to enlighten communities and education stakeholders of the benefits of foundation phase teaching by male teachers.

\section{References}

Akman B., Taskin N., Ozden Z., Okyay O. \& Cortu F. 2014. Parents' views on the appointment of male teachers in Turkish preschool. Education as Change, 18(1):21-32.

Allen, S. \& Daly, K. 2007. The effects of father involvement: An updated research summary of the evidence inventory. Ontario: University of Guelph Centre for 
Families, Work and Well-being. Retrieved from http://www.fira.ca/documents/29/ Effects (accessed 10 May 2013).

Barnett, B. 2009. From theory to classroom: Some practical applications of standpoint theory. Feminist Teacher, 19(3):186-194.

Buzzanell, P.M. 2003. A feminist standpoint analysis of maternity and maternity leave for women with disabilities. Women and Language, 26(2):53-65.

Ching-Sheue, F. \& Kun-Chung, L. 2010. Learning experiences of male pre-service teachers in Taiwan. New Horizons in Education, 58(2):34-42.

Clyde, M. 1994. Men in early childhood: What do women think about it? Early Childhood Education Journal, 29(2):77-82.

Cohen, L., Manion, L. \& Morrison, K. 2000. Research Methods in Education. London: Routledge/Falmer.

Cohen, T.F. 1993. What do fathers provide? In J.C. Hood (Ed.), Men, Work and Family. Newbury Park, CA: Sage. 1-22.

Cooney, M.H. \& Bittner, M.T. 2001. Men in early childhood education: Their emergent issues. Early Childhood Education Journal, 29(2):7-82.

Drury, S. 2008. Gender balance/gender bias: The teaching profession and the impact of feminisation. Gender and Education, 20(4):309-323.

Edmonds-Cady, C. 2009. Getting to the grassroots: Feminist standpoints within the welfare movement. Journal of Sociology and Social Welfare, 36(2):11-33.

Fagan, C. 1996. Gendered time schedules: Paid work in Great Britain's social politics. International Studies in Gender, State and Society, 3(1):72-106.

Gardiner, S.M. 2011. A Perfect Moral Storm: The Ethical Tragedy of Climate Change. New York: Oxford University Press.

Griffin, E.M. 2009. A first look at communication theory. Boston, MA: McGrawHill Education.

Lamb, M.E. 2000. The effects of interviewer gender and child gender on the informativeness of alleged child sexual abuse victims in forensic interviews. Law and Human Behaviour, 27(2):157-171.

McClelland, C.E. 2002. The German Experience of Professionalization: Modern Learned Professions and Their Organizations from the Early Nineteenth Century to the Hitler Era. Cambridge: Cambridge University Press.

McKenzie, M.N. 2012. Gender roles and South Africa. Retrieved from http:// interuwcmag.wordpress.com/2011/11/10/gender-roles-and-south-africa (accessed 25 January 2014).

McMillan, J. \& Schumacher, S. 1993. Research in Education: A Conceptual Introduction. New York: Longman.

Miles, M.B. \& Huberman, A.M. 1994. An introduction to content analysis. London: Sage Publishers. 
Mukuna, T.E. \& Mutsotso, S.N. 2012. Gender Inequalities in Early Childhood Development Education Teaching Profession in Kenya. Educational Research, 2(13):1876-1885.

National Association for the Education of Young Children. 2010. Using children's literature to debunk gender stereotypes. Retrieved from http://www. newfoundations.com (accessed 2 February 2014).

Petersen, N. \& Petker, G. 2011. Foundation phase teaching as a career choice: Building the nation where it is needed. Education as Change, 15(1):49-61.

Petersen, N. 2014. The 'good', the 'bad' and the 'ugly'? Views on male teachers in foundation phase education. South African Journal of Education, 34(1):1-13.

Rodriguez, E. 1997. What does gender have to do with it? Male teachers in early childhood education. Gender and Education, 20(4):586-593.

RSA DoE (Republic of South Africa. Department of Education). 2001. Education White Paper Five on Early Childhood Education. Pretoria: Government Printers.

Sak, R., Sahin, I.K. \& Sahin, B.K. 2012. Views of female pre-service teachers about male teaching colleagues. Social and Behaviour Sciences, 47:586-593.

Sanders, K. 2002. Viewpoint: Men do not care? Young Children, 57(6):44-48.

Sargent, P. 2001. Real men, real teachers: Contradictions in the lives of men elementary school teachers. Harriman, TN: Men's Studies Press.

Shonkoff, J.P. \& Bales, S.N. 2011. Science does not speak for itself: Translating child development research for the public and its policymakers. Child Development, $82(1): 17-32$.

Shonkoff, J.P., Richter, L., Van der Gaag, J. \& Bhutta, Z.A. 2012. An integrated scientific framework for child survival and early childhood development. Pediatrics, 129(2):460-472.

Sobiraj, S., Korek, S., Weseler, D. \& Mohr, G. 2011. When male norms don't fit: Do traditional attitudes of female colleagues challenge men in non-traditional occupations? Sex Roles, 65:798-812.

Sumsion, J. 2005. Male teachers in early childhood education: Issues and case study. Early Childhood Research Quarterly, 20(1):109-123.

Wood, J.T. 2008. Critical Feminist Theories: Giving voice and visibility to women's experience in interpersonal communication. In D.O. Braithwaite \& L.A. Baxter (Eds.), Engaging Theories in Interpersonal Communication: Multiple Perspectives. Thousand Oaks, CA: Sage. 323-334. 